\title{
PROTECTED AREAS, COMMUNITY COSTS AND BENEFITS: A COMPARATIVE STUDY OF SELECTED CONSERVATION CASE STUDIES FROM NORTHERN KWAZULU-NATAL, SOUTH AFRICA
}

\author{
Sakhile NSUKWINI* \\ University of Mpumalanga, School of Biology and Environmental Sciences, \\ Mbombela, South Africa, e-mail: Sakhile.Nsukwini@ump.ac.za

\section{Urmilla BOB} \\ University of KwaZulu-Natal, School of Agriculture, Earth and Environmental Sciences, \\ College of Agriculture, Engineering and Sciences, Durban, South Africa, e-mail: bobu@ukzn.ac.za
}

\begin{abstract}
Citation: Nsikwini S. \& Bob U. (2019). PROTECTED AREAS, COMMUNITY COSTS AND BENEFITS: A COMPARATIVE STUDY OF SELECTED CONSERVATION CASE STUDIES FROM NORTHERN KWAZULU-NATAL, SOUTH AFRICA. GeoJournal of Tourism and Geosites, 27(4), 1377-1391. https://doi.org/10.30892/gtg.27422-441
\end{abstract}

\begin{abstract}
Communities neighbouring protected areas globally suffer various costs while enjoying limited benefits from conservation areas. This study compared livelihood costs and benefits to selected neighbouring communities around the Somkhanda Game Reserve (SGR), which is a community-owned conserved area and the Hluhluwe-iMfolozi Park (HiP), a state-owned, provincial park in northern KwaZulu-Natal. Quantitative (questionnaire) and qualitative (focus groups and interviews with key informants) methods were used to examine the livelihood impacts of the two conservation study sites on neighbouring communities. The political ecology and the sustainable livelihood framework guided the research. The most common livelihood costs incurred in both neighbouring communities include loss of land, curtailed access to traditionally used natural resources, destruction of crops and devouring of livestock by wild animals, loss or injury of human life by wildlife and the spreading of wildlife diseases to livestock. Benefits included employment opportunities, business opportunities, access to natural resources and collection of firewood. The identified livelihood costs from the two conservation areas have further been aggravated by lack of compensation to affected households. The study recommends that measures should be taken to strengthen problem animal control in the two conservation areas. Furthermore, both conservation areas should come up with some compensation criteria to cover affected households.
\end{abstract}

Key words: human wildlife conflict, livelihood costs and benefits, state-owned conservation area, community-based conservation area

\footnotetext{
* Corresponding author
} 


\section{INTRODUCTION}

The dawn of colonialism during the $18^{\text {th }}$ and $19^{\text {th }}$ centuries in Africa saw the twin processes of land and wildlife alienation which created hostility to wildlife among the affected local people (Munien et al., 2018). Musavengane and Simatele (2016a) assert that colonialism was the entry point through which the fortress conservation doctrine entered its way into Africa. This is common in South Africa as shown by Musavengane et al. (2019) in the case of the KwaGumbi community in northern KwaZulu-Natal where communities were forcefully removed to make way for wildlife conservation. Fortress conservation is a mode of conservation that spearheaded human-nature dichotomy through the conceptualisation of native resource users as the conservation problem (Makindi, 2016). Africans apart from being ignored, were overwhelmed, manipulated, and outmanoeuvered by a conservation crusade led, orchestrated, and dominated by white settlers. Above all, control over natural resources was taken away from them, and livelihood practices such as traditional hunting was criminalised (Chigonda, 2018). This is supported by Lubilo \& Hebinck (2019) who indicate that the colonisers became avid gamekeepers and the Africans the poachers and the rural poor had to suffer the consequences of living with wildlife while reaping no benefits from wildlife conservation. As a result, one of the dominant conclusions that may be drawn from the decades of research on the social dynamics of biodiversity conservation is that protected areas (PAs) have added hardship to households in rural communities throughout much of the African countries (Musavengane \& Simatele, 2016b; Thondhlana \& Shackleton, 2013).

Consequently, PAs in Africa share common salient features: historical poor public relations and minimal support from local communities thus the land where the natives once hunted game both for food and ritual became enclosed and privatised and what was once an everyday practice became illicit overnight (Bragagnolo et al., 2016; Swemmer et al., 2017). Hence, PAs have been heavily criticised for preserving nature for a wealthy elite thus, this ethnocentric conservation strategy characterised with exclusion has not gained acceptance, as it works against the economic and social interests of local people, and frequently transformed wildlife from an asset into a threat and nuisance (Bennett \& Dearden 2014). Soliku \& Schraml (2018) suggest that PAs should not exist as islands, divorced and isolated from the social, cultural, and economic context in which they are located. PAs in most developing and independent countries have paid attention to the issue of communities deriving benefits from them and they have made this phenomenon become a more practical and ethical necessity: practical, because to survive, PAs in the poorer nations must be seen as a land-use that contributes positively to sustainable development as the other types of land-use, and ethical, because human rights and aspirations need to be assimilated into national and global conservation strategies if social justice is to be realised (Riehl et al., 2015).

Meilby et al. (2014) and Musavengane \& Simatele (2016b) state that biodiversity conservation has come to be seen as a viable option to support sustainable community development particularly in the rural areas of developing countries. They further argue that many of the rural poor in the world live within or in close proximity to biologically diverse areas (included designated conservation areas), with the majority of them highly dependent on natural resources for meeting their basic needs and engaging in income generating opportunities (Anthony \& Swemmer, 2015). In recent years, after a period of strictly centralised wildlife management and exclusive wildlife conservation, there has been a commendable attempt to balance the needs for conservation with those for rural development (Snyman \& Bricker, 2016). In an effort to redress the colonial injustices, well-meaning conservationists have embraced the paradigmatic shift in the conservation 
of wildlife from the historical separatist conservation approaches termed conservation against the people (Matseketsa et al., 2018) to present day community-based natural resources management (Muboko, 2017). Thus, the modern movement in conservation now recognises PAs to be socio-ecological systems as it has been proven beyond doubt that no PA can succeed for long with local opposition at the community level (Swemmer et al., 2017). Beyond these advancements, narrowing down to the South African case study, post-apartheid (especially after 1994) has championed the resurgence of restoring the right to own and manage wildlife that had been denied in the colonial and apartheid era to rural communities (Kepe \& Hall, 2018). In this regard, the state pioneered the People and Parks initiative under the then Department of Environmental Affairs and Tourism (DEAT) and now Department of Environmental Affairs (DEA) (Pelser et al., 2013). However, there is limited research that examines the extent to which local communities neighbouring PAs benefit or incur losses due to conservation efforts in general.

Additionally, among the growing and important body of knowledge that examines community perceptions of the conservation areas and the impacts of living in close proximity to these locations, there is a dearth in the number of studies that compare issues in relation to community-owned or state-owned PAs. The objectives of this study were therefore to establish the nature of costs incurred by communities living adjacent to the two conservation areas, determine the benefits local communities derive from the two PAs, and assess local communities' attitudes towards the two PAs. In light of the above, this study examines costs and benefits derived by local communities neighbouring selected PAs in northern KwaZulu-Natal pursuing wildlife conservation with development goals. The ultimate aim is to assess whether neighbouring communities to two conservation areas derive any crucial benefits or suffer the costs of residing next to PAs. Research on wildlife conservation and livelihood in South Africa has not addressed the question of whether community-owned or state-owned PAs contribute negatively or positively to the livelihoods of adjacent communities. This paper, therefore, attempts to add to literature on how state-owned and community-owned PAs in South Africa are positively and negatively contributing to livelihoods of local communities in their immediate locality. A comparative analysis using two case studies of the Somkhanda Game Reserve (SGR), which is a community-owned conserved area and the Hluhluwe-iMfolozi Park (HiP), a state-owned, provincial park in northern KwaZulu-Natal is undertaken.

\section{CONCEPTUAL FRAMEWORK}

This section presents the theoretical underpinning for examining biodiversity conservation in relation to the political ecology and sustainable livelihood approach in both the respective PAs in South Africa. The political ecology perspective is used to understand the social, economic as well as environmental dimensions of conservation with respect to biodiversity and rural development. The article draws from the political ecology and sustainable livelihoods framework (SLF) as theoretical guides to understand and discuss of the links between PAs' costs and benefits towards the sustainability of rural livelihoods. In this article, a political ecology framework is used to aid the interrogation of community conservation policies and practice in South Africa and the ideological perspectives that underpin them. In particular, attention is focused on the extent to which current natural resources management and governance policies, institutional frameworks and practice are largely a product of history and reflect the interests of various actors with varying agendas; how the new discourse of sustainable development has gained ascendancy in environmental policy and is reconfiguring the relationship between the environment and livelihoods; and the extent to which policy derivatives of this discourse 
represent local realities and interests surrounding livelihoods costs and benefits in relation to biodiversity conservation. The questions that arise through this framework as outlined by Barr et al. (2009) include:

- Who the actors involved in natural resource policy processes and management are?

- How they shape local access to natural resources?

- What power do they hold?

This power, according to Barr et al. (2009), include:

- The power to create or modify rules and regulations;

- The power to make decisions about how a particular natural resource should be used;

- The power to implement the policies, rules and regulations and ensure compliance; and

- The power to adjudicate disputes that arise in the implementation and enforcement of rules.

However, it is important to note that although political ecology has been useful in providing an understanding of broad-scale factors that shape access to natural resources, it is limited in providing a critical reflection of how local livelihoods are constructed on a day-to-day basis (Dube, 2019). It is argued that in addition to these external factors, individual agency and local factors are important in shaping access to natural resources (Green, 2016). This is also relevant in the South African context where powerful actors (conservation agencies) tend to overpower weaker actors (local communities) in the name of conserving biodiversity and in the process local communities loose their livelihoods.

Initiatives such as community-based conservation (CBC), community-based natural resources management (CBNRM) and others focus on devolving power to the local level and ensure that local communities partake in decision-making processes. However, in reality the literature shows that communities are usually told what is going to happen (Fletcher, 2017; Green, 2016; Riehl et al., 2015). To complement the political ecology approach, the SLF is also used. According to Su et al. (2019), a perspective that best represents local agency is the SLF. This perspective overlaps with political ecology in several ways. Like political ecology, a livelihood perspective is highly interdisciplinary and not bound by the intellectual restraints of narrower disciplines (Wei et al., 2018).

The perspective is also committed to the analysis of complex factors shaping access to natural resource management at the local level (Musinguzi et al., 2018). There are three major reasons for drawing on a sustainable livelihood perspective in addition to insights from political ecology (discussed earlier) as articulated by Harbi et al. (2018):

- A livelihood perspective provides a more critical reflection of local livelihoods that can enhance human understanding of rural livelihoods and how natural resources such as forests constitute an important part of diversified rural livelihood strategies.

- A livelihood perspective has a more developed body of concepts that this study can easily draw on (that is, it provides organising concepts for local level studies).

- Livelihoods is an important entry point in any discussion of socio-ecological issues.

The focus on livelihoods is crucial because adequate and secure livelihoods are central to people's concerns about well-being in developing countries and, as such, society's relationship to the environment in these countries must be seen in the context of broader capacities and strategies for livelihoods construction (Downie et al., 2018).

In this regard, a livelihood perspective allows the article to focus on the extent to which natural resource policies and strategies are in harmony with the organisation of local livelihoods (costs and benefits) in study sites. Enhanced livelihoods in rural areas such as HiP and SGR can be measured using the SLF. Some studies (Adeleke \& Nzama, 
2013; Nsukwini \& Bob, 2016) in KwaZulu-Natal have used the SLF to understand the role of the ecotourism sector in the development of rural areas. Adeleke and Nzama (2013) used the SLF to assess the participation levels of marginalised rural communities in the HiP. These studies have, however, not adequately examined the benefits and costs of protected areas to local communities. The SLF has become popular to the discourse on poverty reduction, rural development and environmental management (Scoones, 2009). According to Chambers \& Conway (1992: 7), "a livelihood comprises capabilities (resources, claims and access) and activities required for a means of living". Furthermore, Downie et al. (2018) state that a livelihood comprises assets (natural, physical, human, financial and social capital), the activities and the access to these (mediated by institutions and social relations) that collaboratively determine the living gained by the individual or household. The SLF is, therefore, a suitable approach for analysis of livelihoods in this study as it links the broader socio-economic components of household assets, livelihoods activities, outcomes of livelihoods activities and factors mediating access to livelihood activities (Downie et al., 2018; Scoones, 1998). The SLF shows how in different contexts and through various strategies people support themselves through access to a variety of resources or assets such as natural, economic, human, financial and social capitals (Chambers \& Conway, 1992; Downie et al., 2018; Scoones, 2009). In this article, the extent to which the case study communities use natural resources (found within protected areas) such as wildlife, forest resources, grass, firewood, wild food and fruits to improve their livelihoods is analysed using the SLF and the political ecology perspectives.

\section{MATERIALS AND METHODS Description of study sites}

The research data was collected from local communities (at household level) and the management staff (conservation officials) of the two PAs, HiP and SGR, one representing a government managed provincial game reserve and another one representing a community managed game reserve, respectively. Both study sites are found in KwaZulu-Natal, one of South Africa's nine provinces which has a high spatial footprint of conservation areas and rural populations. The HiP is a 90 ooo hectares game reserve in the Province of KwaZulu-Natal, managed by the Ezemvelo KwaZulu-Natal Wildlife (EKZNW) which is the conservation authority responsible for the management of all state-owned PAs in KwaZulu-Natal (Figure 1) (Ezeuduji et al., 2017). It is known as the oldest game reserve in Africa, established in 1895 (Michel, 2019). Furthermore, Nsukwini \& Bob (2016) assert that HiP is the oldest game sanctuary in Africa. In terms of historical significance, iMfolozi can be seen as the site where Zulu war victories were celebrated as well as the royal hunting ground of King Shaka (Adeleke \& Nzama, 2013). Local traditional authorities through amakhosi (the chiefs) are central in the management of natural resources in HiP (Adeleke, 2015). The Mpembeni community under the Hlabisa Traditional Authority and the KwaSeme community under the AbakwaHlabisa Traditional Authority were chosen as the focus of the study and are referred to in this article as communities surrounding HiP. The HiP was chosen as a study area because it is surrounded by dense human populations and has increasingly degraded subsistence agriculture which typifies the situation in which many conservation areas exist in developing countries, especially in Africa (Nsukwini \& Bob, 2016).

To enable a comparative analysis, the SGR is a 16418.82 hectare community game reserve, owned by the Gumbi community who are also referred to as the Somkhanda community located in UPhongolo Local Municipality in the Zululand District Municipality in northern KwaZulu-Natal Province (see Figure 1). SGR is surrounded by 
five settlement areas: Zonyama, Cotlands, Hlambanyathi, Bethal and Candover. According to the local Headman (Induna in the local isiZulu language) as cited in Musavengane \& Simatele (2016a), there are approximately 312 households in the Gumbi community. The Gumbi people who were forcibly removed from their land in 1960s were restored land under the land reform process in 2005 (Musavengane, 2019). The Gumbi is the main tribe that resides in the Gumbi community and now proud owners of the land that was previously settled by white game farmers (Musavengane \& Leonard, 2019).

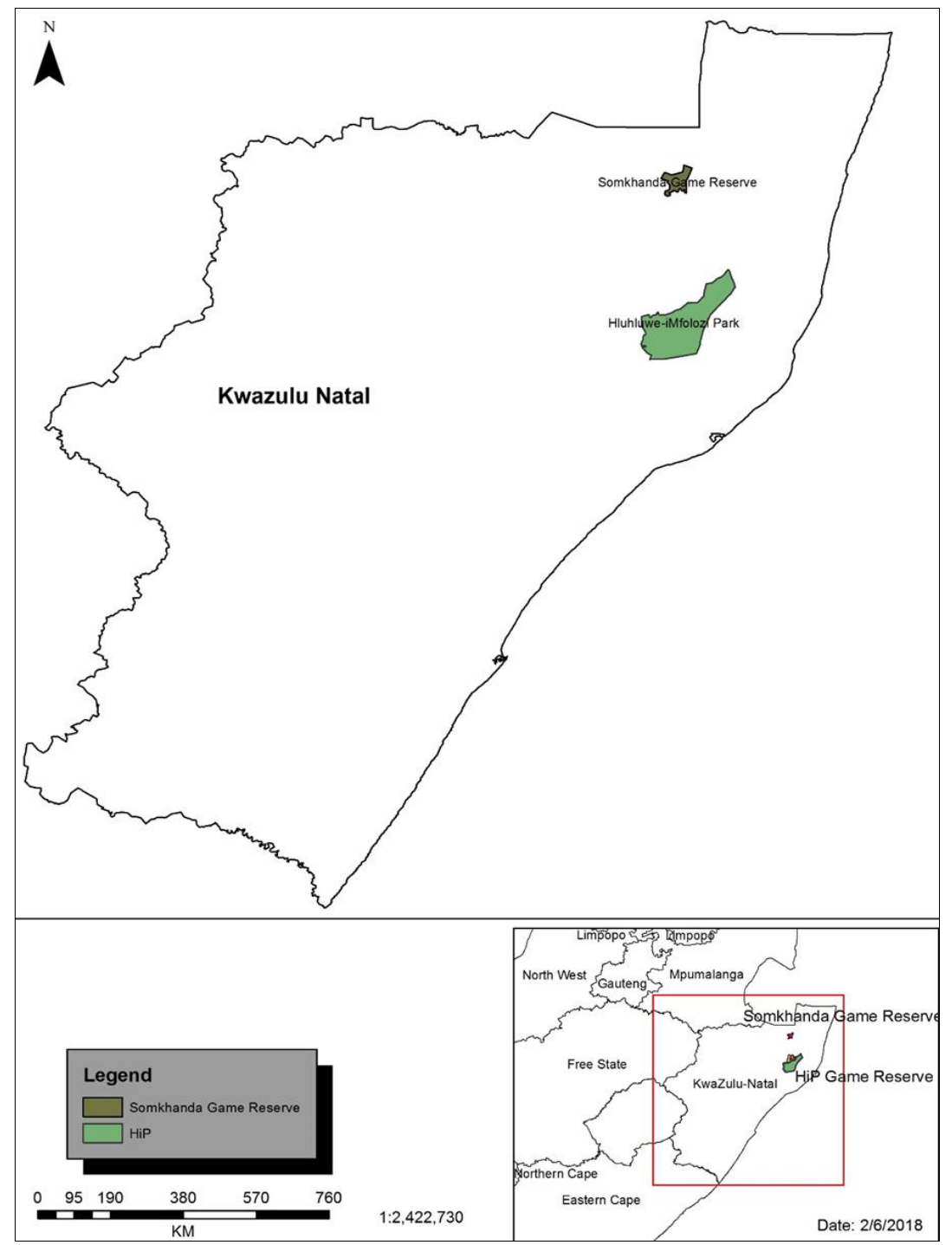

Figure 1. Map of KwaZulu-Natal showing the location of study sites

After claiming the land, the Gumbi people decided to keep large portions of the land under conservation and create a consolidated game reserve, SGR, for economic and social development in the community. According to one of the founders and beneficiaries 
of SGR, the community partnered with the Wild Trust (referred to as Wildlands henceforth) after failing to manage it on their own for the first five years after successfully claiming the land. The Emvokweni Community Trust contracted Wild Trust to manage and transfer skills to local community members. The Emvokweni Community Trust is a legally, constituted board responsible for operations of the SGR. They are the owners of the game reserve and members are voted in by land beneficiaries.

The Emvokweni Community Trust also leased a tourism section to African Insight so that they oversee all tourism operations. Both entities (the Wild Trust and African Insight) are operating on a 5-year lease agreement. They established collaborative necessitated skills development projects that would ensure transference of skills from conservation groups to local people. The reserve is the first community-owned private wildlife reserve to be created from land reform processes in South Africa (Musavengane \& Simatele, 2016a). According to Wildlands Conservation Trust, the game reserve spans 16 418.82 hectares of land, settlement and grazing area has 5209.40 hectares and still 11 508.72 hectares are still pending land claim (Dudley et al., 2014).

\section{Methodological approaches}

Both quantitative (questionnaire) and qualitative (interviews, group discussions and observation) data collection techniques were used in gathering primary data for the study. Mixed methods research or triangulation enables the use of multiple methods in data collection which paves way for collecting credible, reliable and valid data. The questionnaire targeted the residents adjacent to the two conservation areas, and solicited information on livelihood costs and benefits from the HiP and SGR, respectively.

Communities adjacent to HiP have an approximate household population of 1200 while communities neighbouring the SGR have 312 households. One hundred and fifty households were selected for questionnaire interviews from each of the two communities through simple random sampling. Key informants were also interviewed so as to collect in-depth information on livelihood costs and benefits from the two conservation areas.

In HiP, the key informants included the community conservation officer, conservation manager, park ecologist, Amakhosi (the chiefs), ward councillor, and executive committee members of the Rhino Ridge Lodge. In SGR, key informant interviews were held with the park manager, tourism manager, community conservation representative, Emvokweni Community Trust committee representatives and the traditional leadership. The key informants were selected using the purposive sampling technique. To obtain further in-depth information on livelihood costs and benefits from the conservation areas, two focus group discussions were held, one in HiP and another in SGR. Each of the two focus group discussions had a total of 12 participants, chosen carefully so as to ensure representativeness in terms of gender, age, level of education and socio-economic status. Observations were also crucial in getting first hand information on the livelihood costs and benefits from the conservation areas to the case study communities. Information was collected as it happened or as it had happened, for example, concerning human-wildlife conflicts, the use of natural resources, construction and others. Quantitative data was converted into percentage and frequency tables, while qualitative data was analysed thematically.

\section{RESULTS DISCUSSIONS}

The study sought to establish the livelihood costs and benefits incurred by the communities neighbouring the HiP and SGR. These are presented and discussed below using the comparative approach. Understanding and incorporating the social backdrop in which community conservation initiatives are implemented allows a more robust analysis 
of project outcomes. As such, data reveal that communities adjacent to HiP and SGR can be classified as having high levels of unemployment $70.7 \%$ of the respondents for HiP and $80 \%$ for SGR were unemployed). Unemployment was highlighted as a major concern among in both communities during the focus group discussions and key informant interviews as well. These results are disconcerting, given that the majority of respondents (21\% for HiP and 37\% for SGR) were between 26 and 35 years old (economically active age category). Additionally, the heavy reliance on state grants (social aid) (59\%) and pensions (42\%) as a sources of household income further highlights the economic instability and vulnerability experienced by respondents. This also suggests high levels of dependency amongst respondents. These findings align with census data that show a $54.3 \%$ dependency within the two communities under the study.

The high levels of poverty that characterise both of the communities were also reinforced during the focus group discussions and key informant interviews. This resonates with other researchers who have highlighted the vulnerabilities and poverty experienced by communities residing adjacent to conservation areas (Bragagnolo et al., 2016; Chigonda, 2018; Munien et al., 2018). In this regard, biodiversity conservation initiatives have the potential to significantly enhance local development and socioeconomic benefits through job creation. Incorporating the immediate needs of the local communities as part of project outcomes may also improve community participation through acceptance and the appeal of improved income generating potential.

Table 1 summarises livelihood costs to the communities adjacent to HiP and SGR from the two conservation areas. Slightly more than half of the questionnaire respondents in HiP (50.7\%) and SGR (52.7\%) indicated that the conservation areas have restrictions on acesss to, and use of traditional resources.

Table 1. Costs to the community from living near conservation areas (in \%, yes responses only): multiple responses

\begin{tabular}{|l|c|c|c|}
\hline \multicolumn{1}{|c|}{ Conservation challenges to community } & $\begin{array}{c}\text { HiP } \\
(\mathrm{n}=15 \mathrm{O})\end{array}$ & $\begin{array}{c}\text { SGR } \\
(\mathrm{n}=15 \mathrm{O})\end{array}$ & $\begin{array}{c}\text { Total } \\
(\mathrm{n}=300)\end{array}$ \\
\hline Restriction on access to, and use of traditional resources & 50.7 & 52.7 & 51.7 \\
\hline Loss of land and livelihoods & 51.3 & 43.3 & 47.3 \\
\hline Damage to property and crops by wildlife & 72.7 & 54.7 & 63.7 \\
\hline Human harassment by wildlife & 33.3 & 37.3 & 35.3 \\
\hline No consultation by conservation authorities on boundaries & 22.0 & 43.3 & 32.7 \\
\hline Hostility and harassment by conservation enforcement agents & 12.7 & 29.3 & 21.0 \\
\hline Competition with wildlife for water and grazing & 35.3 & 14.7 & 25.0 \\
\hline Cannot expand agricultural land & 38.7 & 14.7 & 26.7 \\
\hline Were moved out of the conservation area when it was formed & 96.0 & 90.7 & 93.3 \\
\hline
\end{tabular}

Access to traditional resources from the natural environment is critically important in rural areas since they are a source of food (thereby contributing to food security), fuelwood, medicine, inputs for homestead construction (such as thatch grass for roofing and poles), materials for arts and crafts, etc. (Meilby et al., 2014). In addition, 51.3\% of the respondents in HiP and $43.3 \%$ in SGR indicated that the conservation areas had led to loss of land and livelihoods. Additionally, $72.7 \%$ of the respondents in $\mathrm{HiP}$ and $54.7 \%$ in SGR indicated damage to property and crops by wildlife with a further $33.3 \%$ in HiP and $37.3 \%$ in SGR stating human harassment by wildlife. In relation to livelihoods, $35.3 \%$ of the respondents in HiP and $\mathbf{1 4 . 7 \%}$ in SGR identified competition with wildlife for water and grazing while $38.7 \%$ in $\mathrm{HiP}$ and $\mathbf{1 4 . 7 \%}$ in SGR noted that they cannot expand 
agricultural land. While differences are discernible in the two case study sites, especially greater costs for people residing near the government game reserve than the community managed game reserve, the results indicate that substantial proportions of community members have negative experiences associated with the PAs which impact on their livelihoods. This is in agreement with conservation literature stating that most communities adjacent to conservation areas historically predate the PAs, have preexisting rights to resources in them and have often been adversely affected by their designation. As noted earlier, the setting up of most PAs in South Africa has resulted in the displacement and resettling of the people who originally inhabited these areas.

It is important to note that both the HiP and the SGR have been established in areas that were previously inhabited by people. Both study sites (HiP and SGR) have some evidence of graves and old buildings that prove that people once settled the conservation areas. In the case of SGR, during the focus group discussions and key informant interviews it emerged that the area now occupied by the community conservation area was once settled by the people who now stay in five villages around the Gumbi community and some relocated to neighbouring towns of Jozini, Nongoma, Magudu, Hluhluwe and Mtubatuba. The people were displaced and resettled during the colonial and apartheid era in the 1920 s and 1940 s when the apartheid government took over from colonialists and the responses in Table 1 are a clear indication that such memories are still fresh and embedded in communities' minds with almost all respondents (96\% for HiP and 90.7\% for SGR) stating that family members were moved out of the conservation area when it was formed. Furthermore, one resident of Cotlands village adjacent to the SGR indicated that:

The land now occupied by SGR was forcefully taken from us by the apartheid government in the 1960 s and we were forced to work for them without being paid.

Some respondents from SGR further indicated that the land in villages where they were relocated to was more infertile land compared to those inside the SRG. This was confirmed in an interview with the induna (headman) for the area. After 1994 when the democratic government took over, the Gumbi community successfully claimed the land from the previous white farm owners who took the land from them.

The people of Gumbi agreed to establish the SGR in anticipation of benefiting from conservation and tourism activities in the park. However, many respondents and participants during the focus group discussion in SGR noted with concern that, since the establishment of SGR, they have not benefited from it except for the few community members who are connected to Emvokweni Community Trust committee members.

Furthermore, community respondents also cited concerns of lack of tangible benefits from the SGR and accused the current Emvokweni Community Trust committee members of corruption. This is an important finding in that while it is generally understood and accepted that in South Africa public and private conservation areas are products of apartheid and colonisation which neglected the rights and needs of indigenous local people, the results from this study reveal that community-based game reserves also fail to address community needs and aspirations.

Political and power dynamics in the community, as alluded to when adopting a political ecology lens, are evident. There are also concerns in relation to the lack of consultation by conservation authorities on park boundaries. Additionally, more respondents in SGR (29.3\%) compared to HiP (12.7\%) stated that they experienced hostility and harassment by conservation enforcement agents. This is surprising given that the SGR is on claimed land by the community. Thus, caution should be exercised to 
assume that community-based PAs are better positioned or will be more sensitive to community needs. This is reinforced by the findings which indicate that competition with wildlife for water and grazing areas, damage to property and crops by wildlife and cannot expand agricultural land had substantially lower responses from the SGR compared to HiP.

For all other costs examined, almost equal proportions or more respondents from SGR compared to HiP identified aspects covered (access to traditional resources, loss of land and livelihoods, human harassment by wildlife, attitude of conservation enforcement agents and forcibly moved) as concerns. Community respondents in HiP and SGR were also asked whether they require access to the two conservation areas for various activities and natural resources that are central to their livelihoods. The community respondents from both conservation areas showed that some people desired having access to the two PAs for various resources and activities. The most identified resource/ activity in Table 2 was food gathering. There was a substantially higher need for access to resources from the SGR than HiP with more than 60\% requiring access for fuelwood collection, grazing, cultivation, irrigation and for cultural/ social purposes. Less than $30 \%$ of the respondents in HiP identified the need to access HiP for these resources/ activities. This can be attributed to the fact that the HiP is surrounded by ten tribal authorities and that it occupies the larger piece of land than SGR. Furthermore, HiP relocated a significant number of community members during it proclamation in the 1800 s than the SGR that only relocated the Gumbi community (Musavengane \& Simatele, 2016a).

Table 2. Whether respondents required access into protected area for various resources/ activities (in \%, yes responses only): multiple responses

\begin{tabular}{|c|c|c|c|}
\hline Resource/activity required in conservation areas & $\begin{array}{c}\text { HiP } \\
(\mathrm{n}=15 \mathrm{O})\end{array}$ & $\begin{array}{c}\text { SGR } \\
(\mathrm{n}=15 \mathrm{O})\end{array}$ & $\begin{array}{c}\text { Total } \\
(\mathrm{n}=300)\end{array}$ \\
\hline Grazing & 25.3 & 62.7 & 44.0 \\
\hline Recreation & - & 15.3 & 7.7 \\
\hline Food gathering & 88.7 & 78.7 & 83.7 \\
\hline Cultivation & 20.7 & 61.3 & 41.0 \\
\hline Fuelwood collection & 28.0 & 66.7 & 47.3 \\
\hline Irrigation & 20.0 & 61.3 & 40.7 \\
\hline Cultural/social & 19.3 & 61.3 & 40.3 \\
\hline
\end{tabular}

The community responses indicate that the proclamation of the conservation areas had resulted in loss of land and the curtailment of residents from accessing traditionally used natural resources, which are central to the livelihoods of communities.

The conservation authorities in both conservation areas, however, indicated that no one was allowed access into the PAs for any activities, except for recreational and cultural/ social activities. Furthermore, the community conservation officers in both PAs indicated that local communities are allowed free access to the parks during the month of September for a week as part of the national people and parks initiatives. Local schools from the communities adjacent to the two PAs are also allowed free access at any time of the year as promoting environmental education. In order to allow comparative analysis, community respondents from both HiP and SGR were asked whether any of their household member worked/ work in a PA and the majority (91.3\% in HiP and 90\% in SGR) of respondents from both study sites indicated no. This continues to be a major issue in relation to conservation efforts in developing contexts which communities are often persuaded to support on the basis that they will provide economic benefits, linked to 
tourism opportunities. The high levels of unemployment noted earlier together with the lack of job opportunities in the area are a major contributor to rural poverty.

Results on benefits show that a higher proportion of the respondents from the household survey (compared to those who identified costs earlier) do not perceive community benefits associated with residing near the respective conservation areas which reflects dissatisfaction with the nature of benefits derived from the two conservation areas (Table 3). The main benefits identified were being able to see and know different kinds of wild animals and business opportunities. The latter is again associated with the perception that PAs create income-generating opportunities for communities.

Fewer respondents identified firewood, employment opportunities and getting game meat. Differences in both the case studies are discernible. Furthermore, the findings of this study indicate a different situation to what was discovered by Simelane et al. (2006) in their study on the six national parks under the South Africa National Parks (SANParks) about their knowledge and understanding of resources that occurs within the six national parks. More community respondents from both HiP and SGR cited the knowledge of different kinds of wild animals in the two parks as one of the benefits of residing next to a conservation area. It can be observed that the demand for fuelwood by adjacent communities in both study sites emerged to be low compared to other studies conducted elsewhere in Africa. The employment opportunities cited by focus group discussion participants and key informant interviews in both PAs were mainly seasonal employment which are created by both parks through their expanded public works programme (EPWP) initiatives which are funded under the working for water and the working for fire initiatives. These are the programmes that create employment opportunities for women and youth in surrounding communities to PAs (Adeleke, 2015).

Table 3. Community benefits perceptions of residing next to a conservation area (in \%, yes responses only): multiple responses

\begin{tabular}{|l|c|c|c|}
\hline \multicolumn{1}{|c|}{ Benefits of residing next to a protected area } & $\begin{array}{c}\text { HiP } \\
(\mathrm{n}=15 \mathrm{O})\end{array}$ & $\begin{array}{c}\text { SGR } \\
(\mathrm{n}=15 \mathrm{O})\end{array}$ & $\begin{array}{c}\text { Total } \\
(\mathrm{n}=300)\end{array}$ \\
\hline Able to see and know different kinds of wild animals & 62.7 & 42.0 & 52.3 \\
\hline Get game meat & 1.3 & 36.0 & 18.7 \\
\hline Help with transport & - & 4.0 & 2.0 \\
\hline Firewood & 12.0 & 20.0 & 16.0 \\
\hline Business opportunities & 48.7 & 36.0 & 42.3 \\
\hline Employment opportunities & 10.7 & 21.3 & 16.0 \\
\hline
\end{tabular}

It emerged during the focus group discussions and key informant interviews that the dissatisfaction expressed with regard to benefits derived can be due to the awarding of benefits at community level and not at the household level. Other studies have demonstrated that local people hold favourable attitudes toward wildlife conservation when personal benefits are derived from PAs. Hansen (2013) suggests that communities dislike communal benefits; rather, they enjoy them at individual and household levels. This is largely because most wildlife-induced costs (such as crop raiding and livestock kills) are borne and felt at the household level rather than the entire community (Spierenburg \& Brooks, 2014). Essentially, community benefits undermine people's short-term needs and create a loophole for free riders as they barely address that question of who pays for and who benefits from wildlife (Godfrey, 2013).

Ngubane \& Brooks (2013) argue that benefits from conservation initiatives targeting the entire community rather than the individual households are condemned 
as they are termed public goods which the culprits and non-victims get to enjoy. Also, given the definition of community conservation, both study sites satisfy the definitional parameters on paper but not on the ground, as community members are highly antagonistic which can be attributed to the poor flow of benefits to the communities as noted by Pailler et al. (2015). Depoliticising conservation issues in the two study sites is imperative so as to ensure solidarity among multiple stakeholders which is vital for integrated conservation and development. Also, failure of community leaders in particular and community members in general to recognise laws and policy frameworks authorising them to profit from conservation outcomes further impedes the derivation of concrete benefits from the two study sites. In HiP, the business opportunities that few of the respondents identified are the sale of crafts to tourists (Table 4).

Fewer respondents stated sale of vegetables and other food to lodges and access to foreign currency. The low response rates in SGR can be attributed to the fact that the reserve has only limited accommodation for visitors and that is it does not receive many tourists like the HiP. Furthermore, the sale of crafts to tourists (the main income generating opportunity available for community members living close to conservation areas that attract large numbers of visitors as is the case of HiP) in SGR emerged to be significantly low because the area does not receive many tourists and it can also be attributed to the state of infrastructure (specifically limited road infrastructure and poor quality where roads are in existent) that do not favour tourists with small cars travelling to the area. During the focus group discussion it was noted that communities in Somkhanda are offering home stays to tourists that visit the park to learn about the history and culture of the Gumbi community. The extent to which households benefit from these home stays requires further investigation.

Table 4. If conservation areas have stimulated any business opportunities for communities (in \%, yes responses only): multiple responses

\begin{tabular}{|l|c|c|c|}
\hline \multicolumn{1}{|c|}{ Business opportunities } & $\begin{array}{c}\text { HiP } \\
(\mathrm{n}=15 \mathrm{O})\end{array}$ & $\begin{array}{c}\text { SGR } \\
(\mathrm{n}=15 \mathrm{O})\end{array}$ & $\begin{array}{c}\text { Total } \\
(\mathrm{n}=300)\end{array}$ \\
\hline Selling of crafts to tourists & 37.3 & 5.3 & 21.3 \\
\hline Selling of vegetables and other food to lodges & 7.3 & $5 \cdot 3$ & 6.3 \\
\hline Access to foreign currency & 1.3 & 3.3 & 2.3 \\
\hline
\end{tabular}

Table 5. Alternative community development activities to be funded by conservation areas identified (in \%, yes responses only): multiple responses

\begin{tabular}{|l|c|c|c|}
\hline \multicolumn{1}{|c|}{ Alternative community development activities } & $\begin{array}{c}\text { HiP } \\
(\mathrm{n}=15 \mathrm{O})\end{array}$ & $\begin{array}{c}\text { SGR } \\
(\mathrm{n}=15 \mathrm{O})\end{array}$ & $\begin{array}{c}\text { Total } \\
(\mathrm{n}=300)\end{array}$ \\
\hline Agricultural expansion & 25.3 & 73.3 & 49.3 \\
\hline Expansion of rural service centres & 22.7 & 51.3 & 37.0 \\
\hline Livestock rearing & 9.3 & 48.0 & 28.7 \\
\hline Infrastructural development & 34.7 & 42.7 & 38.7 \\
\hline
\end{tabular}

In relation to responses regarding the types of community development activities that should be funded by the conservation area, Table 5 reveals that more respondents in SGR identified areas that need to be supported than respondents in HiP. Specifically, $73.3 \%$ of the respondents in SGR and $25.3 \%$ in HiP would like the PA management authorities in their respective areas to assist with agricultural expansion. Furthermore, $34.7 \%$ of the respondents in HiP and $42.7 \%$ in SGR indicated that they would like to see the development of infrastructure funded, while 22.7\% in HiP and 51.3\% in SGR indicated that they would like to see the funding for the expansion of rural service centres. 
Additionally, livestock rearing was identified by $48 \%$ of the respondents in SGR and 9.3\% in HiP. Alternative community development activities that should be funded by conservation areas in their communities also relate to strengthening livelihood options and infrastructure that will have benefits at the household level as well.

The findings suggest that the majority of the people in HiP and SGR want the two PAs to support agricultural activities and expansion of rural service centres so that there would be sustainable and meaningful development in their respective communities and this is in addition to infrastructural development.

Some focus group discussion participants in both study sites identified aridity as a major challenge to farming. They indicated that it would be beneficial to both communities if the two conservation areas can assist with crops that are able to resist drought and also assist the two communities with rainwater harvesting tanks. These types of interventions are critical for sustainable livelihoods.

\section{CONCLUSION}

Contemporary conservation research argues for people-centred approaches that seek to provide multi-level benefits to local communities, especially within developing contexts. However, there is a dearth of information regarding local experiences and perceptions of community conservation initiatives within these contexts.

In this regard, the present study examined the benefits and costs endured by communities surrounding the two conservation areas in northern KwaZulu-Natal. From the study findings, it can be concluded that costs outweigh benefits for local communities living adjacent to HiP and SGR. Furthermore, both conservation areas have no formal benefit sharing mechanisms, leading to local communities having negative attitudes towards them and biodiversity conservation in general.

It is recommended that costs incurred by local communities can be offset by a number of actions such as putting in place formalised benefit sharing mechanisms to ensure more consistent flows of benefits to local people living on the edge; deliberate affirmative action where locals should be employed as a form of benefit of living close to a PA; and more detailed information on the economic, social, and opportunity costs of both study sites on local communities thus creating inventories.

These inventories can support the development of conservation and community development strategies to minimise the burden of the two PAs on local communities living in close proximity to these areas while sustainably managing biodiversity. The training of local residents to promote sustainable tourism activities that are integrated into the PA marketing strategies and product portfolio (such as tourists visiting local communities to engage in cultural tourism activities and purchasing arts and crafts as well as having the communities engage in agricultural activities to supply the PA restaurants and accommodation facilities) should also be initiated.

These types of activities will create income-generating opportunities for local people and improve their livelihoods thereby creating a more favourable climate for conservation. The management of both PAs should help to secure markets for local products; and holistically, management authorities need to have the capacity to embark on regular outreach programmes to dialogue with community members and to listen to their concerns. Regular dialogue will help induce pro-conservation attitudes, reduce acrimony, and curtail conflict situations.

\section{Aknowledgments}

The authors would like to acknowledge the support of the National Research Foundation (NRF) and University of KwaZulu-Natal for funding. We would also like to 
acknowledge the particants of the study from both the study sites for participating in the study. This work would have not been possible without the support of Professor Ric Bernard from the University of Mpumalanga.

\section{REFERENCES}

Adeleke, B., O. (2015). Assessment of residents' attitude towards ecotourism in KwaZulu-Natal protected areas. International Journal of Culture, Tourism and Hospitality Research, 9 (3): 316-328.

Adeleke, B., O., \& Nzama, T. (2013). Assessment of community participation in ecotourism and conservation at Hhuhuwe-Umfolozi Park, South Africa. Journal of Environment and Earth Science, 3 (3): 27-37.

Anthony, B.P., \& Swemmer, L. (2015). Co-defining programme success: identifying objectives and indicators for a livestock damage compensation scheme at Kruger National Park, South Africa. Journal of Nature Conservation, 26, 65-77.

Barr, C., I., Resosudarmo, J., McCarthy, J., \& Dermawan, A. (eds). (2009). Decentralisation of forest administration in Indonesia: Implications for forest sustainability, economic development and community livelihoods. Bogor: CIFOR.

Bennett, N., J., \& Dearden, P. (2014). Why local people do not support conservation: Community perceptions of marine protected area livelihood impacts, governance and management in Thailand. Marine Policy, 44: 107-116.

Bragagnolo, C., Malhado, A., C., Jepson, P., \& Ladle, R., J. (2016). Modelling local attitudes to protected areas in developing countries. Conservation and Society, 14 (3): 163-182.

Chambers, R., \& Conway, G. (1992). Sustainable rural livehoods: Practical concepts for the $21^{\text {st }}$ century. Institute of Development Studies (IDS) Discusion Paper 296, Brighton: University of Sussex.

Chigonda, T. (2018). More than just story telling: A review of biodiversity conservation and utilisation from precolonial to postcolonial Zimbabwe. Scientifica (Cairo), Article ID: 6214318.

Downie, B., K., Dearden, \& P., King, L. (2018). Exploring paradoxes in the search for sustainable livelihoods: A case study from Tanzania. Environment, Development and Sustainability, 20 (2): 527-542.

Dube, N. (2019). Voices from the village on trophy hunting in Hwange district, Zimbabwe. Ecological Economics, 159: 335-343.

Dudley, N., MacKinnon, K., \& Stolton, S. (2014). The role of protected areas in supplying ten critical ecosystem services in drylands: A review. Biodiversity, 15 (2-3): 178-184.

Ezeuduji, I., O., Mdiniso, J., M., \& Nzama, A., T. (2017). Assessing nature conservation and tourism development effectiveness towards Local Economic Development in South Africa: Nuanced by the perceptions of local communities? Acta Universitatis Danubius. Economica, 13 (6): 224-239.

Fletcher, R. (2017) Connection with nature is an oxymoron: A political ecology of "nature-deficit disorder", The Journal of Environmental Education, 48:4, 226-233, DOI: 10.1080/00958964.2016.1139534

Godfrey, E. (2013). Peanut butter salvation: The replayed assumptions of 'community'-conservation in Zambia. Journal of African Studies, 31 (3): 380-398.

Green, K., E. (2016). A political ecology of scaling: Struggles over power, land and authority. Geoforum, 74: 88-97.

Hansen, M. (2013). New geographies of conservation and globalisation: The spatiality of development for conservation in the iSimangaliso Wetland Park, South Africa. Journal of Contemporary African Studies, 31 (3): 481-502.

Harbi, J., Erbaugh, J., T., Sidiq, M., Haasler, B., \& Nurrochmat, D., R. (2018). Making a bridge between livelihoods and forest conservation: Lessons from non timber forest products' utilisation in South Sumatera, Indonesia. Forest Policy and Economics, 94: 1-10.

Kepe, T., \& Hall, R. (2018). Land redistribution in South Africa: Towards decolonisation or recolonisation? Politikon, 45 (1): 128-137.

Lubilo, R., \& Hebinck, P. (2019). 'Local hunting' and community-based natural resource management in Namibia: Contestations and livelihoods. Geoforum, 101: 62-75.

Makindi, S., M. (2016). Local communities, biodiversity conservation and ecotourism: A case study of the Kimana Community Wildlife Sanctuary, Kenya. African Journal of Hospitality, Tourism and Leisure, 5 (3): 1-15.

Matseketsa, G., Chibememe, G., Muboko, N., Gandiwa, E., \& Takarinda, K. (2018). Towards an understanding of conservation-based costs, benefits, and attitudes of local people living adjacent to save Valley Conservancy, Zimbabwe. Scientifica, https://doi.org/10.1155/2018/6741439.

Meilby, H., Smith-Hall, C., Byg, A., Larsen, H., O., Nielsen. Ø., J., Puri, L., \& Rayamajhi, S. (2014). Are forest incomes sustainable? Firewood and timber extraction and productivity in community managed forests in Nepal. World Development, http://dx.doi.org/10.1016/j.worlddev.2014.03.011. 
Michel, A. (2019). An investigation into whether poaching creates an ecological trap for white rhinoceros in Hluhluwe-iMfolozi Park, South Africa. Unpublished dissertation.

Muboko, N. (2017). The role of transfrontier conservation areas and their institutional framework in natural resource-based conflict management: A review. Journal of Sustainable Forestry, 36 (6): 583-603.

Munien, S., Phungula, S., \& Bob, U. (2018). Tourism potential, economic impacts and implications in marginalised areas in Ndwedwe Municipality, KwaZulu-Natal, South Africa. EuroEconomica, 37 (2): 63-75.

Musavengane, R. (2019). Land reform and the promotion of collaborative community-based ecotourism at Somkhanda Game Reserve, South Africa. Positive Tourism in Africa. no page numbers available.

Musavengane, R., \& Leonard, L. (2019). When race and social equity matters in nature conservation in postapartheid South Africa. Conservation and Society, 17(2): 135-146,

Musavengane, R., \& Simatele, D., M. (2016a). Social capital and the pursuit of ecotourism as a land-use option in land reformed communities: A study of KwaZulu-Natal's tribal Areas, South Africa. African Journal of Hospitality, Tourism and Leisure, 5 (4): 1-21.

Musavengane, R., \& Simatele, D., M. (2016b). Community-based natural resource management: The role of social capital in collaborative environmental management of tribal resources in KwaZulu-Natal, South Africa. Development Southern Africa, 33 (6): 806-821.

Musavengane, R., Tantoh, H.B., \& Simatele, D. (2019). A Comparative Analysis of Collaborative Environmental Management of Natural Resources in Sub-Saharan Africa: A study of Cameroon and South Africa. Journal of Asian and African Studies 1-21

Musinguzi, P., Bosselmann, A., S., \& Pouliot, M. (2018). Livelihoods-conservation initiatives: Evidence of socioeconomic impacts from organic honey production in Mwingi, Eastern Kenya. Forest Policy and Economics, 97: 132-145.

Ngubane, M., \& Brooks, S. (2013). Land beneficiaries as game farmers: Conservation, land reform and the invention of the 'community game farm' in KwaZulu-Natal. Journal of Contemporary African Studies, 31 (3): 399-420.

Nsukwini, S., \& Bob, U. (2016). The socio-economic impacts of ecotourism in rural areas: A case study of Nompondo and the Hluhluwe-iMfolozi Park (HiP). African Journal of Hospitality, Tourism and Leisure, 5: 1-15.

Pailler, S., Naidoo, R., Burgess, N., D., Freeman, O., E., \& Fisher, B. (2015). Impacts of community-based natural resource management on wealth, food security and child health in Tanzania. PloS One, 10(7): e0133252.

Pelser, A., Redelinghuys, N., \& Velelo, N. (2013). Protected areas as vehicles in population development: Lessons from rural South Africa. Environment, Development and Sustainability, 15 (5): 1205-1226.

Riehl, B., Zerriffi, H., \& Naidoo, R. (2015). Effects of community-based natural resource management on household welfare in Namibia. PloS One, 10(5): eo125531.

Scoones, I. (2009). Livelihoods perspectives and rural development. The Journal of Peasant Studies, 36 (1): $171-196$.

Simelane, T., S., Kerley, G., I., H., \& Knight, M., H. (2006). Reflections on the relationships between communities and conservation areas of South Africa: The case of five South African national parks. Koedoe, 49 (2): 85-102.

Snyman, S., \& Bricker, K., S. (2016). Living on the edge: Benefit-sharing from protected area tourism. Journal of Sustainable Tourism, 24 (10): 1480-1481.

Soliku, O., \& Schraml, U. (2018). Making sense of protected area conflicts and management approaches: A review of causes, contexts and conflict management strategies. Biological Conservation, 222: 136-145.

Spierenburg, M., \& Brooks, S. (2014). Private game farming and its social consequences in post-apartheid South Africa: Contestations over wildlife, property and agrarian futures. Journal of Contemporary African Studies, 32 (2): 151-172.

Su, M., M., Wall, G., Wang, Y., \& Jin, M. (2019). Livelihood sustainability in a rural tourism destination-Hetu Town, Anhui Province, China. Tourism Management, 71: 272-281.

Swemmer, L., Mmethi, H., \& Twine, W. (2017). Tracing the cost/ benefit pathway of protected areas: A case study of the Kruger National Park, South Africa. Ecosystem Services, 28: 162-172.

Thondhlana, G., \& Shackleton, S. (2013). Cultural values of natural resources among the San people neighbouring Kgalagadi Transfrontier Park, South Africa. Local Environment, 20 (1): 18-33.

Wei, F., Wang, S., Fu, B., Zhang, L., Fu, C., \& Kanga, E., M. (2018). Balancing community livelihoods and biodiversity conservation of protected areas in East Africa. Current Opinion in Environmental Sustainability, 33: 26-33.

Submitted:

02.09.2019
Revised:

17.12.2019
Accepted and published online 19.12.2019 